\title{
Environmentální vzdělávání veřejnosti
}

\section{Jana Laciná, Vlastimil Kostkan}

Envigogika 8 (3) - Inspirace (Nerecenzované články)/ Inpiration (Non-reviewed articles)

Publikováno/published 15. 10. 2013

http://dx.doi.org/10.14712/18023061.391

Mgr. Jana Laciná,

projektová manažerka a jednatelka, Conbios s. r. o, jana.lacina@conbios.eu

RNDr. Vlastimil Kostkan,

projektový manažer a jednatel, Conbios s. r. o., vlastimil.kostkan@conbios.eu

\begin{abstract}
Abstrakt
Ochrana životního prostředí je $v$ demokratické společnosti výsledkem spolupráce veřejné správy, občanů a komerčních subjektů. Tato spolupráce, pokud má být konstruktivní, musí být založena na objektivních informacích z oblasti biologie, ekologie i dalších, převážně společensko-vědních oborů, které do ochrany životního prostředí přesahují. Skupiny (stakeholders), zapojené do těchto procesů, by měly mít ve všech těchto oborech adekvátní znalosti i prístup k nejnovějším poznatkům, a schopnost prezentovat je ve srozumitelné formě. Starší generace občanů v České republice zcela postrádá ekologické vzdělání (ekologie nebyla do sedmdesátých let minulého století v této společnosti uznávána jako věda) a mladší generace potřebuje průběžné informace o nových poznatcích z environmentálních oborů. $Z$ těchto zkušeností vyšel návrh projektu REGOL, zaměřený na vzdělávání široké veřejnosti i profesionálů na regionální úrovni v nejnovějších poznatcích vědy, nezbytných pro rozhodování o ochraně přírody a krajiny.
\end{abstract}

\section{Klíčová slova}

vzdělávání, environmentální, ekosystémové služby, veřejnost, learning by doing, krajina, príroda, interaktivní workshopy 


\section{1. Úvod}

Ochrana životního prostředí má v současné době řadu specializovaných odvětví, která se zaměřují na snahy zmírnit vlivy člověka na globální klima atd. až po ochranu jednotlivých vymírajících organizmů. Specifickou problematikou je ochrana prírody a krajiny, zejména ve venkovských regionech, jež Ize u nás rovněž shrnout pod pojem „kulturní krajina". Tedy prostředí, které obklopuje především obyvatele malých měst, vesnic i jednotlivých samot, ale které do značné míry ovlivňuje i životní prostředí ve městech. A právě stav kulturní krajiny je, snad více než kterákoliv jiná složka životního prostředí, ovlivňován ekonomickými aktivitami a životem lidí na venkově. Hospodaření na zemědělské půdě a v lesích je jedním ze základních činitelů, které na přírodu a krajinu mají vliv a formují je. Stav a budoucí vývoj přírody a krajiny je rovněž velice závislý na rozhodování obecních samospráv a veřejné správy na úrovni menších obcí. Tyto samosprávy a veřejná správa jsou ve venkovských regionech pod daleko větším přímým vlivem veřejnosti, než ve velkých městech nebo větších regionech. $Z$ tohoto důvodu se úroveň environmentálních znalostí široké veřejnosti, zejména na venkově, může významně projevit $v$ dlouhodobých tendencích vývoje životního prostředí venkova, protože environmentálně vzdělaní občané malých obcí mohou významně ovlivnit rozhodování samospráv a veřejné správy na této úrovni.

\subsection{Současný stav životního prostředí a kompetence veřejnosti}

Pokles biodiverzity, degradace půdy a industrializace krajiny představují nevratné změny životního prostředí. O jejich dopadech v podobě ekonomických škod a zhoršování kvality života bohužel nejsme každodenně informováni v denním tisku, protože nejsou tak patrné, jako bankroty firem nebo tunelování veřejných prostředků. Ve skutečnosti se jedná o daleko větší ekonomické škody, jen jejich důsledky přichází se zpožděním (např. budoucí ztráty úrodnosti půd) nebo si je neuvědomujeme ve správných souvislostech (např. miliardové škody způsobené povodněmi jsou z části důsledkem ztráty tzv. „ekosystémových služeb", které poskytuje nenarušená krajina). Pojem ekosystémové služby se v literatuře objevuje od druhé poloviny 20. století, asi nejúplnější definici publikovali Hassan \& Scholes (2005) ${ }^{1}$.

V posledních letech „módní" přivalové nebo též „bleskové" povodně na malých tocích, provázené tisíci kubických metrů bahna splaveného do obcí a lidských obydlí, jsou jen jedním, zato dobře viditelným dưsledkem mnoha dalších změn, které přináší nesprávné hospodaření v krajině. Tyto změny v kvalitě životního prostředí, které se promítají i do našeho života, jsou patrné zejména ve venkovských regionech. Při rozhodování o využití krajiny jsme často svědky takových řešení, která vychází ze zažitých, ale dnes již dávno překonaných a nesprávných stereotypů, založených na 20 i více let starých zdrojích

1 Ekosystémové služby jsou př́nosy, které získáváme z přírody a které zásadním způsobem ovlivňují naši životní úroveň. Můžeme je rozdělit do 4 kategorií:

- $\quad$ podpưrné služby - služby nutné pro vytvoření dalších ekosystémových služeb (např. fotosyntéza, koloběh živin a vody, tvorba půdy),

- zásobovací služby - tzn. produkty získané z ekosystémů (např. potraviny, vlákna, pitná voda, genetické zdroje apod.),

- $\quad$ regulační služby - přínosy získané z regulace ekosystémových procesů (řízení klimatu, čistění vody, regulace eroze, opylování, regulace nemocí atd.),

- kulturní služby - nehmotné prínosy získávané z ekosystémů (rekreace, estetické zkušenosti, duchovní obohacení). 
informací. Navíc, řada norem, metodik a způsobů řešení, používaných před rokem 1990, bylo poplatných minulému režimu a neměly objektivní základ. Následky takových rozhodnutí, které nedokáží vyřešit existující problémy, pak mohou ve veřejnosti vyvolávat pocit, že současná ochrana životního prostředí je neúčinná a ve svém důsledku vede k nezájmu o její obsah, cíle a zejména samotný předmět ochrany.

\section{Hledání řešení v rámci projektu REGOL}

Projekt s názvem „Rozvoj environmentální gramotnosti odborné i laické veřejnosti” (REGOL) si proto kladl za cíl podporu vzdělání veřejnosti venkovských regionů České republiky $v$ oblasti obecných a odborných kompetencí, týkajících se uvedené problematiky. Do projektu byly zapojeny 3 organizace: Bioinstitut o. p. s. jako řešitel, Conbios s. r. o. a Raddit s. r. o. jako partneři. Cílovou skupinou projektu byli především občané, kteří by mohli svým odpovědným přístupem $\mathrm{k}$ ochraně životního prostředí a $\mathrm{k}$ udržitelnému rozvoji přispět ke zlepšení současného stavu. Občané, kteří nemají $v$ rámci svého zaměstnání nebo volného času běžný přístup $\mathrm{k}$ dalšímu vzdělávání na takové úrovni, aby byli schopni analyzovat aktuální vědecké poznatky, a nemají ani možnost se běžně setkávat se srozumitelnými formami interpretace moderních př́stupů k ochraně prírody, krajiny, zemědělství, ochraně půdy, vod, dřevin atd. Pro tuto cílovou skupinu jsou pořádány mnohé kurzy vzdělávající je ve finanční gramotnosti, genderové problematice, právech žen, zdravém životním stylu, vztahu $\mathrm{k}$ hendikepovaným spoluobčanům atd. $\mathrm{V}$ oblasti životního prostředí je však takových kurzů či seminářů velmi málo a lidé tak často nevědí, jak v různých problémových situacích, kdy dochází $\mathrm{k}$ ohrožení životního prostředí $\mathrm{v}$ jejich bezprostředním okolí, reagovat a na koho se obrátit. Přitom, jak uvádí Dytrtová (2004), environmentální výchova a vzdělávání je již dávno považováno za součást obecného vzdělání a mělo by ovlivňovat naše myšlení a rozhodování. Ovšem jak ukazuje praxe, zdaleka ne každý občan si uvědomuje potřebné souvislosti a potřeby udržitelného rozvoje společnosti.

Projekt REGOL měl napomoci tuto situaci zlepšit, zvýšit environmentální gramotnost občanů České republiky (především v moravských krajích, které byly cílovým regionem projektu), poskytnout těmto lidem potřebné informace, odkazy a prípadně kontakty na organizace, které jim mohou být $v$ řešení problémů nápomocny, a $v$ neposlední řadě motivovat občany k aktivnímu přístupu a soustavnému vzdělávání $v$ oblasti ochrany ŽP a udržitelného rozvoje (což si mimo jiné stanovuje za cíl také systém Environmentálního vzdělávání a výchovy dle definice $v$ zákoně č. 561/2004 Sb.). Jedním z cílů projektu bylo tedy vzdělávat tzv. "světoobčany" (dle definice Braniše - viz Dlouhá a kol., 2009), tedy takové občany, kteří jsou informovaní, kritičtí a uvědomělí. Jsou schopní chápat ve všech souvislostech výsledky komplikovaných a komplexních interakcí moderní lidské společnosti a př́rody. Jsou připraveni vzniklé problémy řešit nebo jim dokonce předcházet.

\subsection{Oslovení potenciálních zájemců}

Informace o plánovaných workshopech byly rozesílány prostrednictvím elektronické pošty primárně zástupcům obecních a městských úřadů a magistrátů měst (resp. zástupcům jejich odborů životního prostředí, kteří mají k tématice nejblíže a nejlépe tak vyhodnotí vhodnost informace pro ostatní možné zájemce) ve všech moravských krajích se žádostí, aby tyto informace rozesílali dále svým občanům jakožto potenciálním účastníkům a uchazečùm o vzdělání.

Celkem bylo prímo, tedy e-maily, osloveno přibližně 2000 potenciálních zájemců o daná témata školení. Z toho 1733 e-mailů směřovalo k občanům prostřednictvím 
pracovníků odborů životního prostředí na pověřených obcích a obcích s rozšířenou působností a starostů obcí, dále 111 e-mailů směřovalo nevládním organizacím. Tato skupina byla dále oslovena prostřednictvím pravidelného elektronického zpravodaje Veroniky "Rozverky", který odebírá cca 1400 čtenářù. V adresáŕích dále bylo 108 adres na konzultační, projekční a další komerční firmy a blíže nespecifikovaný počet kontaktů na zájemce $\mathrm{z}$ jiných organizací, kteří osobně již dřive projevili zájem o jakékoliv vzdělávací aktivity $v$ oblasti životního prostředí.

Kromě toho o seminářích informovaly různé reklamy - např. "zelený banner" Zeleného kruhu http://www.zelenykruh.cz/cz/o-nas/zeleny-banner/, reklama v průvodci na výstavě ENVIBRNO a samozřejmě webové stránky všech tří řešitelů projektu. Podle údajů na projektovém webu navštívilo stránky informující o projektu a seminárích od začátku roku 2013 do konce června 2013 celkem více než 1100 tzv. "unikátních" návštěvníků (tedy různých subjektů) a více než polovina návštěvníků se na stránky vracela (celkový počet návštěv stránek dosáhl více než 2500). Největší pohyb návštěvníků na webových stránkách byl zaznamenán vždy ve dnech po rozesílání pozvánek na jednotlivé workshopy, kdy se počty denních přístupů na webové stránky pohybovaly mezi 50-80 návštěvami (tato situace nastala celkem $7 \mathrm{x}$, což zřejmě koresponduje s tím, že postupně bylo pomocí e-mailů avizovaných celkem 7 workshopů na 6 témat (jedno téma se během jara pro velký zájem opakovalo $2 x$ ).

Největší slabinou podobných vzdělávacích projektů se ukazuje problematika "oslovování neoslovených", tedy skutečně široké veřejnosti, která se dosud o ochranu životního prostředí př́liš̌ nezajímala. Většina výše uvedených komunikačních "kanálư", kterými Ize bez významných nákladů informace o vzdělávacích projektech širíit, se týká určité omezené skupiny občanů, kteří se dlouhodobě o ochranu životního prostředí zajímají. $\mathrm{K}$ tomu, aby informace pronikla i mezi širší veřejnost by bylo nezbytné využívat média s největší sledovaností, velmi často komerční televizní a rozhlasové stanice, nejčtenější deníky a časopisy. Všechna výše uvedená média ovšem šíření informace o podobném typu vzdělávání považují za komerční reklamu a vyžadují vysoké poplatky za její šíření. Pokud by tedy informace o vzdělávacích programech měla oslovovat potenciální zájemce těmito cestami, náklady na propagaci by několikanásobně překročily rozpočet na vlastní realizaci seminářù a školení. $V$ projektech operačních programů je však propagace zahrnuta do tzv. nepř́mých nákladů, které tvoří jen malé procento z celkového rozpočtu projektu a tento postup je tedy nereálný.

\subsection{Forma vzdělávání}

Vzhledem $\mathrm{k}$ tomu, že současná věda přináší neustále obrovské množství nových poznatků, jež je obtižné vyhodnotit a zpracovat i pro specialisty ve svém oboru, nebylo možné použít klasickou formu vzdělávání, při které jsou na seminář pozváni vybraní vědečtí pracovníci přednášející své úzce a často jen teoreticky zaměřené prezentace. Taková školení většinou nenabídnou účastníkům žádné návodné vzory a postupy, které by mohli aplikovat ve vlastní praxi. Hledali jsme proto formu vzdělávání, která by v maximální možné míre zapojila účastníky školení do řešení modelových situací, ve kterých lektor postupy usměrňuje a doplňuje, ale konečné řešení sám nenavrhuje. Jedná se o metodu, které se říká "učení prací" nebo "učení vlastní zkušenosti” (learning by doing) (The Geography Discipline Network, 2013). 
Pro školení byla zvolena struktura interaktivních workshopư ${ }^{2}$, přičemž se jednalo o typ vzdělávání, ve kterém je aktivní především vzdělávaný jedinec, nikoli vzdělavatel. Tento přístup je pro účastníky nejen zábavnější než pasivní přihlížení a naslouchání příspěvkům fundovaných odborníků, ale především si prostřednictvím své aktivní účasti na workshopu mnohem více informací zapamatují a v budoucnosti dokážou dále využít. Účastník tady tedy nebyl ten, který pouze přijímá informace, ale sám také mohl ostatním sdělit své zkušenosti s danou problematikou, konzultovat je s "kolegy" - ostatními účastníky - případně také přímo s lektory, kteří byli zvoleni z řad odborníků na životní prostředí, zoologii, dendrologii, krajinný ráz, biologické i „naturové" hodnocení, formy zemědělství, protierozní ochranu, kompostování a zúrodňování půd, spolupráce veřejnosti a veřejné správy atd.

Workshopy byly vždy organizovány jako dvoudenní, přičemž první den byli účastníci přímo $v$ terénu seznámeni s př́klady různých problémových situací. Prostřednictvím odborných lektorů byly účastníkům zprostředkovány informace nejen o aktuálním stavu př́kladových lokalit, ale také o „pozadí", které k dané situaci vedlo, o zúčastněných stranách, které se aktivně podílely na celém procesu řešení situace a o možném dalším vývoji situace. Následovala "teoretická" část, ve které účastníci dostávali zadání k vyřešení různých pilotních situací, při kterých měli využít poznatky z předchozí terénní exkurze, výkladu lektorů i vlastních zkušeností.

Touto formou nácviku řešení modelových situací v rámci interaktivních workshopů se účastníci učili identifikovat problémy, vyhledávat potřebné informace a navrhovat řešení.

Jako ukázku případových studií, představovaných vždy v první den workshopu $v$ rámci exkurze do terénu, uved'me za všechny projekt úpravy sítě cest a mobiliáře v olomouckých parcích, který byl představen na workshopu "dřeviny rostoucí mimo les". Informace předané účastníkům workshopu byly o to hodnotnější, že byly zprostředkovány přímo členy týmu odborníků (na workshopu vystupujících v roli lektorů), kteří se na zpracování uvedeného projektu podíleli a měli tak velmi dobrý přehled o veškerých aspektech a problémech, které tento projekt doprovázely. Velmi přínosná byla rovněž prítomnost pracovníků magistrátu města Olomouce, jakožto zástupců investora celé akce, kteří přinesli praktický i ekonomický vhled do celé situace. Účastníkům workshopu byl tak celý problém většinou přímo $v$ terénu, $v$ městských parcích, představen velmi podrobně a komplexně, což u nich mělo velmi pozitivní ohlas.

Druhý den workshopu byl vždy věnován práci ve skupinách a řešení modelových situací, které vytvářeli především sami účastníci, a lektor pouze pomáhal udržovat správný směr probíhající diskuze. (Jednou ze zvolených metod vedení workshopu byla práce účastníků na základě představeného fiktivního příběhu - účastníci si měli představit, že pracují pro právě vzniklé Ministerstvo vod, a měli pro toto ministerstvo definovat cíle jeho činnosti a priority, na které by se mělo orientovat. Tento způsob "výuky" odpovídá tzv. narativnímu paradigmatu (Fisher, 1985), které tvrdí, že většina lidí si více a lépe než fakta a data $v$ jejich vědeckých souvislostech pamatuje informace ve formě historek, př́běhů. Následně si vždy všechny skupiny vzájemně představily výsledky své práce a na „flipchartových" listech všechna řešení vystavily. Na závěr bloku, pomocí barevných

2 Tato metoda je zcela v souladu s cíli, které byly výstupem mezinárodní konference Education for a Sustainable Future, která se konala 10. a 11. září 2003 v pražském Karolinu a která mj. definovala požadavek na odbourávání konzervativních či některých tradičních metod výuky a upřednostnění takových metod výuky, které by byly aktivizující pro studenty a daly prostor výměně názorů a získání zkušeností v odborné praxi. 
samolepicích štítků, vyhodnotili všichni účastníci ty části prezentací, které považovaly za nejpřínosnější, rozporuplné i ty, které jim připadaly jako špatné.

Cílem workshopů tedy nebylo primárně navýšení odborných znalostí účastníků, ale především rozvoj jejich schopnosti orientovat se $v$ dostupných informačních zdrojích a podpora jejich dovedností posoudit pravdivost a relevantnost informací pro řešitelnost problému (Dytrtová, 2004).

\subsection{Ohlas účastníků na témata a formu vzdělávání}

Interaktivní workshopy přinesly mimo jiné informace o úrovni znalostí nezbytných pro řešení výše uvedených problémů u zapojených občanů.

Jedním ze zajímavých zjištění celého projektu byl fakt, že zájem o workshopy ze strany "laické" veřejnosti byl velice malý. Kromě několika individuálně přihlášených účastníků se z řad "laiků" zúčastnili workshopů především zástupci nevládních organizací. Důvodů pro malý zájem ze strany laické veřejnosti může být více (nevhodné časování workshopů na všední dny, nezájem laické veřejnosti o daná témata apod.), ale konkrétní př́činu nelze (bez potřebných dat - tedy informací právě od této skupiny občanů) přesně stanovit. $V$ některých př́padech je také obtížné stanovit, kdo je vlastně $v$ oboru laik a kdo odborník. Přesnější by možná bylo členění na "profesionály" a "amatéry". V ojedinělých případech byl na workshopech zaznamenán paradox, kdy tzv. "amatéři" v oboru, např. členové nevládních organizací, mají lepší odborné znalosti, než profesionální pracovníci v oboru přímo se dotýkajícím ochrany životního prostředí.

Převážnou většinu účastníků tvořili zástupci pracovníků samotných obecních a městských úřadů a magistrátů měst a zaměstnanci projekčních kanceláŕí a konzultačních firem. Byli mezi nimi především krajinní a zahradní architekti, hodnotitelé krajinného rázu, posuzovatelé vlivů záměrů na životní prostředí a autorizované osoby pro biologické hodnocení a "naturové" posuzování, tedy především tzv. "odborná" veřejnost. O některá témata (např. problematiku dřevin rostoucích mimo les) dokonce zájem ze strany účastníků vysoce převyšoval kapacitní možnosti workshopů. Tato skutečnost pravděpodobně poukazuje na nedostatek vzdělávacích možností právě pro tyto cílové skupiny, které by pokrývaly různé aspekty životního prostředí, jeho ochrany a rozhodování o něm.

\subsubsection{Hodnocení workshopů účastníky}

Celkově byla zvolená témata hodnocena účastníky velmi dobře, z maximálně možných 5 bodů byla workshopům přidělena průměrná hodnota 4,36 .

Celé tři čtvrtiny účastníků by uvítaly další navazující tematické kurzy nejlépe formou série workshopů, pokrývajících větší množství témat, případně příležitostně, dle aktuální potřeby organizovaných seminářů a workshopů zaměřených na konkrétní (aktuální) téma. Tyto dvě formy by uvítala nadpoloviční většina účastníků. Naopak respondenti uvedli, že nejméně atraktivní je pro ně představa dlouhodobého (např. vícedenního nebo $\mathrm{i}$ semestrálního) kurzu.

Nejlépe hodnocenou aktivitou všech workshopů byla terénní exkurze, kterou by v podobném kurzu postrádalo více než $60 \%$ osob a téměř $83 \%$ tuto formu "výuky" preferuje před ostatními možnými. Dále jsou účastníky vítány odborné přednášky lektorů (tedy určitá forma „pasivní" výuky, která pomůže účastníkům "dostat" se do tématu a poskytne základní odborné informace), a to téměř z $50 \%$; zajímavou se jeví také práce ve skupinách při řešení modelových situací a následným hodnocením v plánu (48\% 
respondentů). Nejméně vítanou formou dalšího vzdělávání byla mezi dotázanými elektronická forma (tzv. e-learning) výuky, tedy jedna z nejpasivnějších metod výuky, která je často vnímána jako metoda, která neumožňuje vzdělávanému na cokoli se potřebného odborníka zeptat, zkonzultovat danou problematiku s ostatními vzdělávanými osobami.

Zajímavou zpětnou vazbou bylo také zjištění, že z nabízených témat byla pro účastníky nejvíce atraktivní problematika dřevin rostoucích mimo les a biodiverzity venkovské krajiny (zájem o obě témata projevila přibližně polovina dotazovaných).

\section{Závěr}

Pokud bychom se při hodnocení projektu spokojili pouze s tím, že kritéria stanovená projektem, tedy počet proškolených, byla splněna, asi bychom mohli uzavř́t projekt konstatováním, že vše proběhlo podle předpokladů a stanovené cíle se podařilo splnit. Bohužel nám ale stále $v$ regionech zůstává obrovské množství občanů, kteří se vůbec o možnosti vzdělávat se $v$ tomto oboru nedozvědí.

Otázkou tedy zůstává, co bylo a je př́činou nezájmu většiny laické veřejnosti o témata spojená s ochranou životního prostředí a jak skutečně širokou laickou veřejnost oslovit. Nebo je snad zdrojem nezájmu neodbytný pocit valné většiny lidí, že dané problematice rozumí (stejně tak jako ostatním aktuálním tématům jako je politika, dění ve světě, problematika rasové nesnášenlivosti apod.) a není proto potřeba, aby se dále vzdělávali?

Opomenout nesmíme ani skutečnost, že současná ekologie a biologie se rozvíjí tak rychle, že poznatky ze studia rychle zastarávají a profesionálové v oboru, pokud nepracují na akademických pracovištích, k nim mají omezený přístup. Celoživotní vzdělávání, které by průběžně doplňovalo znalosti získané během studia těchto odborníků, by mělo být rešeno koncepčně a mělo by být soustavné. $V$ tomto směru jeden časově a územně omezený vzdělávací projekt situaci nevyřeší.

\section{Poděkování}

Projekt REGOL, $v$ jehož rámci text vznikl, byl podpořen $v$ rámci Operačního programu Vzdělávání pro konkurenceschopnost (OVPK), který spadá pod Ministerstvo školství České republiky (MŠMT) a probíhal v letech 2012-2013 (číslo projektu CZ.1.07/3.1.00/37.0033). (Více informací naleznete na webové stránce http://www.regol.conbios.eu/).

\section{Seznam použité literatury:}

- Dlouhá, J. a kol. (2009): Vědění a participace. Teoretická východiska environmentálního vzdělávání. Karolinum. 226 s.

- Dytrtová, R. (2004): Pedagogická propedeutika udržitelného rozvoje. Česká zemědělská univerzita v Praze, katedra pedagogiky. $70 \mathrm{~s}$.

- Fisher, W. R. (1985): The Narrative Paradigm: An Elaboration. In Communication Monographs 52. S. 347-367 
- Hassan, R., Scholes R., A., (eds) 2005: Ecosystems and human well-being current state and trends - findings of the Condition and Trends Working Group. Millennium Ecosystem Assessment. Island Press, Washington, DC. 155 pp

- Zákon č. 561/2004 Sb. [online]. 2013 [cit. 2013-09-12]. Dostupné z: http://www.msmt.cz/dokumenty/novy-skolsky-zakon

- The Geography Discipline Network. [online]. 2001 [cit. 2013-08-20]. Dostupné z: http://www2.glos.ac.uk/gdn/gibbs/index.htm 